\title{
COMPREHENSIVE EVALUATION OF SOIL QUALITY AT DIFFERENT STAND DENSITIES OF DENDROCALAMUS MINOR VAR. AMOENUS PLANTATIONS
}

\author{
ZHENG, J. M. ${ }^{1}-$ CHEN, X. Y. ${ }^{2}-$ CHEN, L. G. ${ }^{2}-$ HE, T. Y. ${ }^{1}-$ RONG, J. D. ${ }^{2}-$ LIN, Y. ${ }^{3}-$ \\ ZHENG, Y. S..$^{1,2 *}$ \\ ${ }^{1}$ College of Arts \& Landscape Architecture, Fujian Agriculture and Forestry University, Fuzhou \\ 350002, PR China \\ ${ }^{2}$ College of Forestry, Fujian Agriculture and Forestry University, Fuzhou 350002, PR China \\ ${ }^{3}$ Changle Dahe State-owned Protection Forest Farm of Fujian Province, Changle, Fujian \\ 350212, PR China \\ *Corresponding author \\ e-mail:zys1960@163.com
}

(Received 19 $9^{\text {th }}$ Apr 2020; accepted $10^{\text {th }}$ Jul 2020)

\begin{abstract}
Soil is considered as the fundamental media to provide nutrients to plants for their growth and development. Nevertheless, soil quality is closely related to soil microbes, enzyme activity, soil physicochemical properties, and above-ground biomass. In this study, soil quality evaluation was performed on 17 indicators, including soil physicochemical properties and enzyme activity. For this, the stand density with the highest soil quality score was selected for improving forest productivity and forest management. Stand density and soil layer factors have little effect on physical properties, mainly affecting chemical properties and enzyme activity. Different species have different adaptability to soil nutrients. The stand density of Dendrocalamus minor var. amoenus was positively correlated with total nitrogen, urease, available potassium, and available phosphorus. Nine indicators were screened by principal component analysis to explain soil quality (cumulative proportion of 92.50\%). Among them, Stand $\mathrm{H} 1$ had the highest soil quality score, and the lower stand density is helpful in alleviating competition pressure on light resources, soil nutrition and so on. It is suggested that the future forest management of Dendrocalamus minor var. amoenus should be controlled in the range of $4300 \mathrm{ramet} / \mathrm{hm}^{-2}$, which is more conducive to soil quality.
\end{abstract}

Keywords: coastal sandy, ramet density, soil physicochemical, soil enzymes, clonal species, bamboo

\section{Introduction}

Soil provides nutrients for plant growth and development. Plant litter and rhizosphere effects promote soil nutrient cycling and develop a plant-soil dynamic response relationship (Yang et al., 2016). Various biotic and abiotic factors influence soil quality, such as, soil and vegetation types (Zhang et al., 2018), which affects stand density or ramet densities. Among them, the most significant factors of soil nutrient fluctuation are site quality and stand density (Zhang et al., 2018), which can be influenced by severe and harsh climatic conditions (Japet et al., 2009). Changes in environment and resources play a significant role in regulating stand density and promoting individual climax of plant species (Maherali et al., 2001). Excessive stand density affects plant root growth, interception of light resources, and soil microbial activity in the forest; appropriate stand densities can reduce forest productivity loss caused by intra-species competition and improve the effective use of soil resources (Chen and Li, 2015; Fan et al., 2015). 
Stand density and plant growth are restricted by site conditions (Wang et al., 2004). Studies on soil quality differences under different stand densities have been reported, such as Larix gmelinii forest, Phyllostachys edulis forest, Pinus tabulaeformis forest and Acacia auriculiformis forest stands (Zhao, 2012; Fan et al., 2015). These study sites were mainly concentrated in the mountains and hills, but a few could be found on the sandy coastal land. Recently, to overcome the rapid land degradation and low productivity of sandy coastal areas, bamboo species have been introduced for afforestation in Fujian province, China. Bamboo species have shown strong adaptability to cope with such environmental conditions with fast growth and strong reproductive capabilities. Meanwhile, bamboo species have long fiber to resist strong winds near the coastal line. The soil quality of vegetation cover is higher than that of bare land ( $\mathrm{Tu}, 2014)$. The soil enzyme activities and nutrients under bamboo species on the sandy coastal land have greatly improved the soil quality ( $\mathrm{Tu}, 2014)$. In order to utilize environmental resources, the relationship between different bamboo stand densities and soil quality needs to be further explored. In order to improve the soil quality of sandy land, it plays an important role in the process of artificial forest construction, forest productivity improvement and soil nutrient cycling effect.

Dendrocalamus minor var. amoenus is a woody bamboo species, which is native to south of Guangxi Province, China. It usually was distributed in low altitude hills. This species is clonal species with strong growth ability and drought resistance. It has been reported that soil nutrient variability in bamboo forests is strongly correlated with the response of the underground whip root system (Zhang et al., 2018). Most bamboo root distributed in 0-40 cm soil depth. The whip root system of Pleioblastus amarus is mainly distributed in the 0-40 cm depth (Zhao, 2009). The soil layer concentrates about $90 \%$ of the root system of Bambusa oldhamii in the $0-40 \mathrm{~cm}$ depth $(\mathrm{Li}, 2014)$. Although the root system of Phyllostachys edulis can reach more than $70 \mathrm{~cm}$, the maximum of root volume range to 0-40 cm depth (Luo, 2009). For that reason, it is important to know the effects of various Dendrocalamus minor var. amoenus plantation densities on soil physicochemical properties and enzyme activities at two different vertical depth gradients. We hypothesized that plantation densities and two distinct depths will affect soil quality and enzyme activity. The best stand density plays a sustainable ecological role in regulating bamboo forest production and improving the ecological environment by comprehensive evaluation of soil quality.

\section{Materials and Methods}

\section{Study site}

The study was conducted at Dahe State-owned Protection Forest Farm, which is located $\left(119^{\circ} 40^{\prime}-119^{\circ} 43\right.$ 'E, $25^{\circ} 57^{\prime}-25^{\circ} 59$ 'N) in Changle District, Fuzhou City, Fujian Province, China (Fig. 1). The area falls in the subtropical climate with abundant rainfall. The annual rainy day is about $160 \mathrm{~d}$, concentrated in summer. The average annual precipitation is about $1200 \mathrm{~mm}$. The average annual temperature is $19.2{ }^{\circ} \mathrm{C}$. The highest temperature occurs in July with average $35.6^{\circ} \mathrm{C}$; while the lowest temperatures occur in January with average 0 ${ }^{\circ} \mathrm{C}$. The coastal climate has less frost damage, without snow cover throughout the year. The average annual wind (northeast) speed is about $4.2 \mathrm{~m} . \mathrm{s}^{-1}$. The annual sunshine hours are $1837.6 \mathrm{~h}$. The coastal terrain is mainly sand dunes with a gentle slope, and the sandy coast is more than 10 kilometers from the coastline. These stands of Dendrocalamus minor var. amoenus were planted in 2011 at a spacing of $3 \mathrm{~m} \times 3 \mathrm{~m}$. Since then, no cultural or management practices were adopted until 2018. Each stand densities were surveyed in 
August 2018, and the stand density was determined according to the number of ramets. The population structure characteristics of four kinds of stand densities are shown in Table 1. The sampling site had almost similar altitude within $10 \mathrm{~m}$ asl with $6-8^{\circ}$ slope.

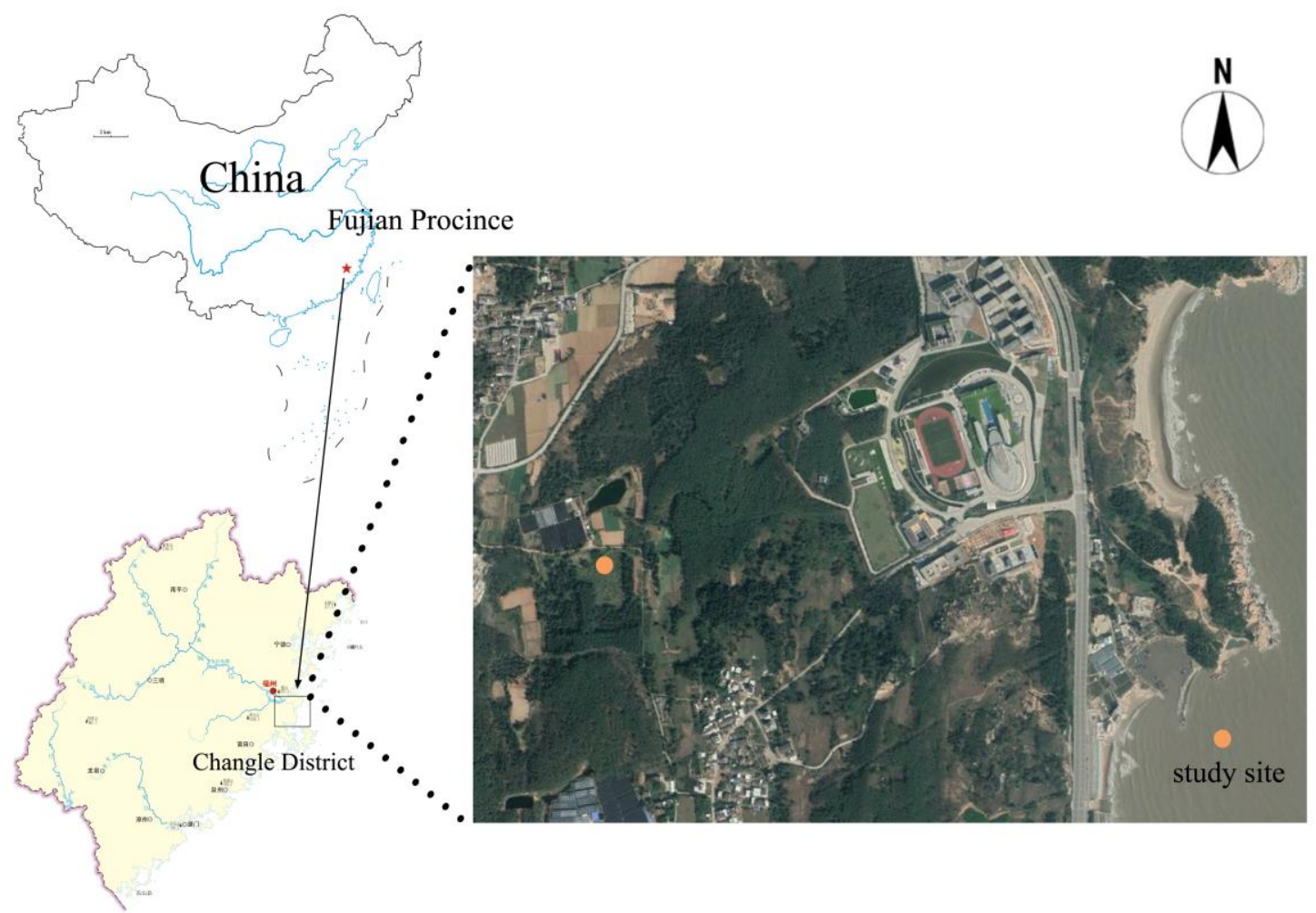

Figure 1. The location of the sampling site

Table 1. Structure characteristics of Dendrocalamus minor var. amoenus populations

\begin{tabular}{c|c|c|c|c}
\hline Stand & Density $\left(\mathbf{R a m e t}_{\left.\mathbf{h} \mathbf{h}^{-\mathbf{2}}\right)}\right.$ & Mean DBH $\mathbf{( c m )}$ & Mean height $\mathbf{( c m})$ & Crown $(\mathbf{c m})$ \\
\hline H1 & $4300 \pm 253$ & 2.12 & 2.93 & 127.00 \\
H2 & $5200 \pm 314$ & 2.33 & 3.50 & 105.00 \\
H3 & $9400 \pm 586$ & 2.67 & 4.04 & 91.50 \\
H4 & $13400 \pm 599$ & 2.66 & 3.95 & 75.80 \\
\hline
\end{tabular}

Values are mean \pm standard deviations

\section{Methods}

Soil sampling and analysis

Samples of soil were randomly collected from different directions in each stand densities (approximately $\left.667 \mathrm{~m}^{2}\right)$ in summer of 2018 . Each plot $(10 \mathrm{~m} \times 10 \mathrm{~m})$ was selected for each stand density. Within each plot, soil samples collected near five randomly selected bamboos (Fig. 2) at three randomly selected points. We collected soil in 0-20 cm and 20-40 cm vertical depth. Roots and litters were carefully removed from the soil before sieving. Each soil sample was divided into two portions for determination of soil physicochemical properties and soil enzyme activities. 


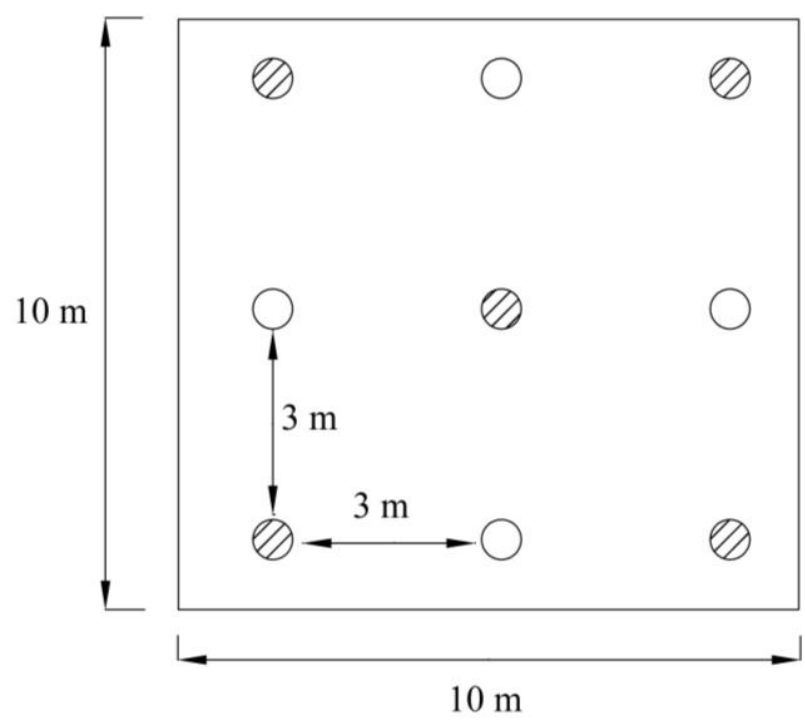

Figure 2. Sampling at the site, which was $10 \mathrm{~m} \times 10 \mathrm{~m}$, and the space of the bamboo was $3 \mathrm{~m} \times$ $3 \mathrm{~m}$. The sampled bamboo is represented by the circle with oblique line

The one portion was air dried for chemical analysis and sieved to $2 \mathrm{~mm}$ to get sub-samples. The $0.149-\mathrm{mm}$ fraction was used for the analysis of total nitrogen (TN), total phosphorus (TP) and total potassium (TK). The 2-mm fraction was used for the analysis of $\mathrm{pH}$, available nitrogen (AN), available phosphorus (AP) and available potassium (AK). The other portion (fresh soil) was stored at $4{ }^{\circ} \mathrm{C}$ immediately after sample collection for soil enzymatic analysis and sieved through a $1 \mathrm{~mm}$ sieve to remove small litter fragments.

\section{Soil physical and chemical analysis}

Volume weight, non-capillary porosity, capillary porosity, total porosity, soil aeration, soil moisture were measured by weighing fresh soil samples after and before drying at $105{ }^{\circ} \mathrm{C}$ to a constant weight (LY/T 1213-1999). The $\mathrm{pH}$ was measured at a soil: water ratio of 1:2.5 (LY/T 1239-1999). TN was measured by the sulfuric acid-mixed accelerator digestion-diffusion method, TK was measured by the sodium hydroxide melt-flame photometer method, the TP was measured by the molybdenum antimony colorimetry, and AN was measured by a sodium hydroxide (sodium hydroxide $(\mathrm{NaOH})$ ) hydrolytic diffusion method, AK was measured by extraction-molybdenum antimony colorimetric method, and AP was measured by ammonium acetate extraction-flame photometry. The detail of these method were under Bao (2005) construction.

\section{Soil enzymatic activities analysis}

Four enzymes were selected for analysis: acid phosphatase, sucrase, urease and catalase. The method of measuring four enzymes were previously described (Qiu et al., 2010). The results were based on three replicates. Acid phosphatase activity was measured the method of Qiu et al. (2010). Urease activity was measured by the indigo colorimetry method. The $\mathrm{NH}_{3}-\mathrm{N}$ released by urease enzymatic hydrolysis of urea was determined colorimetrically at $578 \mathrm{~nm}$, expressed as $\mathrm{NH}_{3}-\mathrm{N} \mathrm{mg} \cdot \mathrm{g}^{-1} \cdot \mathrm{h}^{-1}$. The 
p-nitrophenol (PNP) in the filtrate was determined colorimetrically at $410 \mathrm{~nm}$, expressed as PNP $\mathrm{mg} \cdot \mathrm{g}^{-1} \cdot \mathrm{h}^{-1}$. Sucrase activity was measured by 3,5-dinitrosalicylic acid colorimetry method. Catalase activity was measured by volumetric method.

\section{Comprehensive evaluation of soil quality}

Volume weight (X1), noncapillary porosity (X2), napillary porosity (X3), yotal porosity (X4), soil aeration (X5), soil moisture (X6), $\mathrm{pH}(\mathrm{X} 7)$, total nitrogen (X8), total phosphorus (X9), total potassium (X10), available nitrogen (X11), available potassium (X12), available phosphorus (X13), acid phosphatase (X14), urease (X15), sucrase (X16), catalase (X17) were normalized. Except that Volume weight is a negative effect indicators, the other indicators are positive effect indicators to soil quality. Principal component analysis was used to analyze the eigenvalues, proportion, and cumulative proportion of Principal component. The indicators were then rotated to the load matrix to calculate the $\sigma 2$ of common factor. The weight of each indicator was the proportion of the $\sigma 2$ of common factor to the total $\sigma 2$ of common factor. Principal component correlation coefficients below 0.1 are not displayed. The comprehensive score of soil quality $(\mathrm{F})$ as calculated as equation (1):

$$
\mathrm{F}=\Sigma \mathrm{W}_{\mathrm{i}} \times \mathrm{F}\left(\mathrm{X}_{\mathrm{i}}\right)
$$

where $\mathrm{F}\left(\mathrm{X}_{\mathrm{i}}\right)$ : membership, $\mathrm{W}_{\mathrm{i}}$ : weight of each indicators.

Data analysis

All data were collected using Microsoft Excel 2013, and SPSS 20.0 software (SPSS Inc., Chicago, USA) was used to analyze One-way ANOVA and Least-Significance Difference (LSD) for 17 soil indicators of different stand densities. Principal component analysis was used for calculation Comprehensive score of soil quality at different stand densities.

\section{Result}

\section{Effects of stand densities on Physical properties of soil}

The physical properties of soils of Dendrocalamus minor var. amoenus populations with different densities are shown in Table 2. The volume weight of $0-40 \mathrm{~cm}$ soil layer ranged from $1.15-1.28 \mathrm{~g} / \mathrm{m}^{3}$, noncapillary porosity ranged from $2.52-4.45 \%$, and total porosity ranged from 56.70-66.45\%, soil aeration ranged from 32.06-39.99\%, and the soil moisture is between $6.78-12.24 \%$. In the $0-20 \mathrm{~cm}$ soil layer, the difference between different densities is not significant. In the soil layer $20-40 \mathrm{~cm}$, there are some differences in the total porosity and soil aeration of different densities. Soil aeration of stand $\mathrm{H} 2$ was the lowest.

\section{Effects of stand densities on Chemical properties of soil}

The soil $\mathrm{pH}$ and nutrient content of Dendrocalamus minor var. amoenus populations with different densities are shown in Table 3. $\mathrm{pH}$ ranged from 6.27-6.58 in 0-40 cm depth. Total nitrogen ranged from $0.08-0.26 \mathrm{~g} \cdot \mathrm{kg}^{-1}$, total phosphorus at $0.23-0.27 \mathrm{~g} \cdot \mathrm{kg}^{-1}$, total potassium ranged from $13.47-14.02 \mathrm{~g} \cdot \mathrm{kg}^{-1}$, available nitrogen between 
20.91-38.35 $\mathrm{g} \cdot \mathrm{kg}^{-1}$, and available potassium ranged from $6.06-11.61 \mathrm{~g} \cdot \mathrm{kg}^{-1}$. The available phosphorus was between $1.52-2.77 \mathrm{~g} \cdot \mathrm{kg}^{-1}$. In the $0-20 \mathrm{~cm}$ soil depth, Stand $\mathrm{H} 2$ had the highest total phosphorus content. Stand H1 and H2 had the highest total nitrogen content. Stand $\mathrm{H} 4$ has the highest available phosphorus content. There were no significant differences in $\mathrm{pH}$, total potassium, and available nitrogen at different densities. In the 20-40 cm soil layer, there were no significant differences in available potassium and available phosphorus with different densities. Stand $\mathrm{H} 4$ has the highest $\mathrm{pH}$, stand $\mathrm{H} 1$ and $\mathrm{H} 3$ have the highest total nitrogen content.

Table 2. Soil physical properties in Dendrocalamus minor var. amoenus populations

\begin{tabular}{c|c|c|c|c|c|c|c}
\hline Layer/cm & Stand & $\begin{array}{c}\text { Volume } \\
\text { weight } \\
\left(\mathbf{g} / \mathbf{m}^{\mathbf{3}}\right)\end{array}$ & $\begin{array}{c}\text { Noncapillary } \\
\text { porosity } \\
(\boldsymbol{\%})\end{array}$ & $\begin{array}{c}\text { Capillary } \\
\text { porosity } \\
(\boldsymbol{\%})\end{array}$ & $\begin{array}{c}\text { Total } \\
\text { porosity } \\
(\boldsymbol{\%})\end{array}$ & $\begin{array}{c}\text { Soil aeration } \\
(\boldsymbol{\%})\end{array}$ & $\begin{array}{c}\text { Soil moisture } \\
(\boldsymbol{\%})\end{array}$ \\
\hline \multirow{3}{*}{$0-20$} & $\mathrm{H} 1$ & $1.28 \pm 0.09 \mathrm{a}$ & $3.53 \pm 1.35 \mathrm{a}$ & $62.49 \pm 2.71 \mathrm{a}$ & $66.02 \pm 2.85 \mathrm{a}$ & $39.99 \pm 2.03 \mathrm{a}$ & $10.16 \pm 0.79 \mathrm{a}$ \\
& $\mathrm{H} 2$ & $1.15 \pm 0.13 \mathrm{a}$ & $3.64 \pm 0.98 \mathrm{a}$ & $53.06 \pm 14.74 \mathrm{a}$ & $56.70 \pm 14.86 \mathrm{a}$ & $35.33 \pm 8.13 \mathrm{a}$ & $9.38 \pm 3.07 \mathrm{a}$ \\
& $\mathrm{H} 3$ & $1.25 \pm 0.14 \mathrm{a}$ & $5.37 \pm 1.96 \mathrm{a}$ & $55.00 \pm 6.58 \mathrm{a}$ & $60.37 \pm 7.78 \mathrm{a}$ & $39.16 \pm 1.75 \mathrm{a}$ & $6.78 \pm 3.65 \mathrm{a}$ \\
& $\mathrm{H} 4$ & $1.20 \pm 0.05 \mathrm{a}$ & $3.18 \pm 1.90 \mathrm{a}$ & $61.51 \pm 8.07 \mathrm{a}$ & $64.69 \pm 8.34 \mathrm{a}$ & $38.44 \pm 3.62 \mathrm{a}$ & $10.99 \pm 2.21 \mathrm{a}$ \\
\hline \multirow{3}{*}{$20-40$} & $\mathrm{H} 1$ & $1.19 \pm 0.05 \mathrm{a}$ & $2.52 \pm 0.80 \mathrm{a}$ & $62.03 \pm 2.32 \mathrm{a}$ & $64.54 \pm 3.00 \mathrm{ab}$ & $35.46 \pm 2.10 \mathrm{a}$ & $12.20 \pm 0.84 \mathrm{a}$ \\
& $\mathrm{H} 2$ & $1.23 \pm 0.05 \mathrm{a}$ & $2.90 \pm 0.93 \mathrm{a}$ & $59.15 \pm 2.32 \mathrm{a}$ & $62.05 \pm 2.08 \mathrm{~b}$ & $32.06 \pm 2.43 \mathrm{~b}$ & $12.24 \pm 1.35 \mathrm{a}$ \\
& $\mathrm{H} 3$ & $1.25 \pm 0.05 \mathrm{a}$ & $4.45 \pm 1.61 \mathrm{a}$ & $59.08 \pm 3.73 \mathrm{a}$ & $63.53 \pm 3.29 \mathrm{ab}$ & $35.62 \pm 1.82 \mathrm{a}$ & $12.24 \pm 1.75 \mathrm{a}$ \\
& $\mathrm{H} 4$ & $1.26 \pm 0.09 \mathrm{a}$ & $4.14 \pm 1.68 \mathrm{a}$ & $62.32 \pm 3.96 \mathrm{a}$ & $66.45 \pm 4.69 \mathrm{a}$ & $37.63 \pm 3.30 \mathrm{a}$ & $11.50 \pm 0.92 \mathrm{a}$ \\
\hline
\end{tabular}

Different letters in the same soil layer mean that there are significant different between densities $(P<0.05)$, the same as below. Values are mean \pm standard deviations. H1 means that stand densities of plantation is $4300 \pm 253 \mathrm{ramet} / \mathrm{hm}^{-2}$, details in Table 1

Table 3. Chemical property of soil in Dendrocalamus minor var. amoenus populations

\begin{tabular}{|c|c|c|c|c|c|c|c|c|}
\hline Layer/cm & Stand & pH & $\begin{array}{c}\text { TN } \\
\left(\mathrm{g} \cdot \mathrm{kg}^{-1}\right)\end{array}$ & $\begin{array}{c}\text { TP } \\
\left(\mathrm{g} \cdot \mathrm{kg}^{-1}\right)\end{array}$ & $\begin{array}{c}\text { TK } \\
\left(\mathrm{g} \cdot \mathrm{kg}^{-1}\right)\end{array}$ & $\begin{array}{c}\mathbf{A N} \\
\left(\mathbf{m g} \cdot \mathbf{k g}^{-1}\right)\end{array}$ & $\begin{array}{c}\text { AK } \\
\left(\mathbf{m g} \cdot \mathbf{k g}^{-1}\right)\end{array}$ & $\begin{array}{c}\mathbf{A P} \\
\left(\mathrm{mg} \cdot \mathrm{kg}^{-1}\right)\end{array}$ \\
\hline \multirow{4}{*}{$0-20$} & H1 & $6.37 \pm 0.07 \mathrm{a}$ & $0.26 \pm 0.06 \mathrm{a}$ & $0.26 \pm 0.01 \mathrm{~b}$ & $13.65 \pm 2.55 \mathrm{a}$ & $33.04 \pm 3.12 \mathrm{a}$ & $11.61 \pm 1.90 \mathrm{ab}$ & $1.89 \pm 0.19 b$ \\
\hline & $\mathrm{H} 2$ & $6.30 \pm 0.08 \mathrm{a}$ & $0.24 \pm 0.07 \mathrm{a}$ & $0.27 \pm 0.02 \mathrm{a}$ & $13.47 \pm 2.13 \mathrm{a}$ & $38.35 \pm 10.97 \mathrm{a}$ & $13.51 \pm 2.23 \mathrm{a}$ & $2.09 \pm 0.23 b$ \\
\hline & $\mathrm{H} 3$ & $6.36 \pm 0.08 \mathrm{a}$ & $0.11 \pm 0.02 b$ & $0.25 \pm 0.01 \mathrm{~b}$ & $13.65 \pm 2.28 \mathrm{a}$ & $36.44 \pm 7.05 \mathrm{a}$ & $9.57 \pm 2.54 \mathrm{~b}$ & $2.34 \pm 0.38 \mathrm{~b}$ \\
\hline & $\mathrm{H} 4$ & $6.42 \pm 0.15 \mathrm{a}$ & $0.16 \pm 0.04 \mathrm{c}$ & $0.25 \pm 0.01 \mathrm{~b}$ & $13.75 \pm 3.46 \mathrm{a}$ & $31.54 \pm 3.48 \mathrm{a}$ & $8.74 \pm 2.02 \mathrm{c}$ & $2.77 \pm 0.50 \mathrm{a}$ \\
\hline \multirow{4}{*}{$20-40$} & H1 & & $0.14 \pm 0.13 \mathrm{a}$ & $0.25 \pm 0.03 \mathrm{a}$ & $14.02 \pm 5.99 \mathrm{a}$ & $32.02 \pm 3.93 \mathrm{a}$ & & $1.52 \pm 0.16 \mathrm{a}$ \\
\hline & $\mathrm{H} 2$ & $6.38 \pm 0.04 b$ & $0.08 \pm 0.02 b$ & $0.25 \pm 0.01 \mathrm{a}$ & $13.66 \pm 3.08 \mathrm{ab}$ & $32.53 \pm 5.89 \mathrm{a}$ & $7.56 \pm 2.38 \mathrm{a}$ & $1.64 \pm 0.49 \mathrm{a}$ \\
\hline & $\mathrm{H} 3$ & $6.27 \pm 0.09 b$ & $0.15 \pm 0.09 \mathrm{a}$ & $0.24 \pm 0.01 \mathrm{ab}$ & $13.65 \pm 1.64 \mathrm{ab}$ & $24.47 \pm 7.11 \mathrm{~b}$ & $6.51 \pm 0.30 \mathrm{a}$ & $1.72 \pm .016 \mathrm{a}$ \\
\hline & $\mathrm{H} 4$ & $6.58 \pm 0.05 a$ & $0.08 \pm 0.04 \mathrm{~b}$ & $0.23 \pm 0.01 \mathrm{~b}$ & $13.58 \pm 2.48 \mathrm{~b}$ & $20.91 \pm 7.48 b$ & $6.06 \pm 1.38 \mathrm{a}$ & $1.86 \pm 0.45 \mathrm{a}$ \\
\hline
\end{tabular}

TN: total nitrogen, TP: total phosphorus, TK: total potassium, AN: available nitrogen, AP: available phosphorus, AK: available potassium. Values are mean \pm standard deviations

\section{Soil enzyme activities}

The soil enzyme activities of Dendrocalamus minor var. amoenus populations with different densities are shown in Table 4. Soil acid phosphatase ranged from $0.02-0.09 \mathrm{umol} \cdot \mathrm{d}^{-1} \cdot \mathrm{g}^{-1}$ in $0-40 \mathrm{~cm}$ soil layer, urease ranged from $0.19-0.41 \mathrm{mg} \cdot \mathrm{g}^{-1}$, sucrase was between $0.02-0.49 \mathrm{mg} \cdot \mathrm{g}^{-1}$ and catalase was between $1.22-3.88 \mathrm{mg} \cdot \mathrm{g}^{-1}$. In the $0-20 \mathrm{~cm}$ soil layer, the content of catalase of stand $\mathrm{H} 4$ is the lowest. In the $20-40 \mathrm{~cm}$ soil layer, stand $\mathrm{H} 2$ had the highest urease content. Stand H3 and H4 had the lowest catalase content. There were no significant differences of sucrase between the soil densities and soil layers. 
Table 4. Enzyme activity of soil in Dendrocalamus minor var. amoenus populations

\begin{tabular}{|c|c|c|c|c|c|}
\hline Layer/cm & Stand & $\begin{array}{l}\text { Acid phosphatase } \\
\left(\text { PNP } \text { mg g}^{-1} \cdot \mathbf{h}^{-1}\right)\end{array}$ & $\begin{array}{c}\text { Urease } \\
\left(\mathrm{NH}_{3}-\mathrm{N} \mathrm{mg}^{-1} \cdot \boldsymbol{h}^{-1}\right)\end{array}$ & 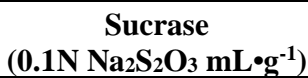 & $\begin{array}{c}\text { Catalase } \\
\left(0.1 \mathrm{~N} \mathrm{KMNO}_{4}{\left.\mathrm{~mL} \cdot \mathrm{g}^{-1}\right)}^{-1}\right)\end{array}$ \\
\hline \multirow{4}{*}{$0-20$} & H1 & $0.08 \pm 0.01 \mathrm{ab}$ & $0.19 \pm 0.08 \mathrm{~b}$ & $0.49 \pm 0.42 \mathrm{a}$ & $3.88 \pm 0.92 \mathrm{a}$ \\
\hline & $\mathrm{H} 2$ & $0.07 \pm 0.01 \mathrm{~b}$ & $0.21 \pm 0.10 \mathrm{~b}$ & $0.11 \pm 0.09 \mathrm{a}$ & $3.88 \pm 0.92 \mathrm{a}$ \\
\hline & $\mathrm{H} 3$ & $0.09 \pm 0.01 \mathrm{a}$ & $0.41 \pm 0.08 \mathrm{a}$ & $0.10 \pm 0.05 \mathrm{a}$ & $3.47 \pm 0.63 \mathrm{a}$ \\
\hline & $\mathrm{H} 4$ & $0.09 \pm 0.04 \mathrm{ab}$ & $0.36 \pm 0.11 \mathrm{a}$ & $0.10 \pm 0.10 \mathrm{a}$ & $2.76 \pm 0.76 \mathrm{~b}$ \\
\hline \multirow{4}{*}{$20-40$} & H1 & $0.02 \pm 0.01 b$ & $0.23 \pm 0.08 \mathrm{~b}$ & $0.05 \pm 0.04 \mathrm{a}$ & $2.65 \pm 0.92 \mathrm{a}$ \\
\hline & $\mathrm{H} 2$ & $0.02 \pm 0.01 \mathrm{~b}$ & $0.40 \pm 0.32 \mathrm{a}$ & $0.16 \pm 0.08 \mathrm{a}$ & $1.63 \pm 0.63 \mathrm{a}$ \\
\hline & $\mathrm{H} 3$ & $0.05 \pm 0.01 \mathrm{a}$ & $0.31 \pm 0.11 \mathrm{~b}$ & $0.02 \pm 0.02 \mathrm{a}$ & $1.22 \pm 0.00 \mathrm{~b}$ \\
\hline & $\mathrm{H} 4$ & $0.04 \pm 0.02 \mathrm{ab}$ & $0.24 \pm 0.10 \mathrm{~b}$ & $0.05 \pm 0.08 \mathrm{a}$ & $1.48 \pm 0.92 \mathrm{~b}$ \\
\hline
\end{tabular}

Values are mean \pm standard deviations

\section{Principal component analysis}

Five principal component factors were extract from 17 indicators. The eigenvalue of the first principal component is 6.99 , which explains $41.11 \%$ of the total proportion. The cumulative proportion of the five principal component factors is $92.50 \%$, which can be better expressed 17 indicators (Table 5). There are nine indicators were screened, volume weight, noncapillary porosity, soil aeration, total phosphorus, total potassium, available nitrogen, available phosphorus, acid phosphatase and urease.

Table 5. Principal component analysis of soil indicators

\begin{tabular}{|c|c|c|c|c|c|c|c|}
\hline \multirow{2}{*}{ Indicators } & \multicolumn{5}{|c|}{ Principal component } & \multirow{2}{*}{$\sigma 2$ of common factor } & \multirow{2}{*}{ Weight } \\
\hline & 1 & 2 & $\mathbf{3}$ & 4 & 5 & & \\
\hline Volume weight & -0.430 & & -0.127 & -0.127 & 0.879 & 0.9896 & 0.0629 \\
\hline Noncapillary porosity & -0.102 & 0.341 & -0.817 & -0.282 & 0.244 & 0.9330 & 0.0593 \\
\hline Capillary porosity & -0.652 & & 0.640 & 0.147 & 0.349 & 0.9815 & 0.0624 \\
\hline Total porosity & -0.744 & & 0.473 & & 0.451 & 0.9878 & 0.0628 \\
\hline Soil aeration & -0.215 & 0.828 & & 0.250 & 0.392 & 0.9552 & 0.0607 \\
\hline Soil moisture & -0.453 & -0.623 & 0.589 & -0.133 & & 0.9672 & 0.0615 \\
\hline $\mathrm{pH}$ & -0.786 & 0.163 & 0.234 & & -0.118 & 0.7197 & 0.0458 \\
\hline Total nitrogen & 0.497 & 0.230 & & 0.751 & 0.173 & 0.8931 & 0.0568 \\
\hline Total phosphorus & 0.913 & 0.151 & & 0.289 & -0.228 & 0.9970 & 0.0634 \\
\hline Total potassium & & & 0.845 & -0.160 & & 0.7580 & 0.0482 \\
\hline Available nitrogen & 0.914 & 0.285 & & & -0.104 & 0.9389 & 0.0597 \\
\hline Available potassium & 0.728 & 0.367 & -0.187 & 0.526 & & 0.9773 & 0.0622 \\
\hline Available phosphorus & & 0.903 & & -0.181 & -0.219 & 0.9084 & 0.0578 \\
\hline Acid phosphatase & 0.305 & 0.869 & -0.296 & & 0.144 & 0.9587 & 0.0610 \\
\hline Urease & 0.118 & 0.128 & & -0.961 & & 0.9532 & 0.0606 \\
\hline Sucrase & 0.291 & 0.187 & 0.180 & 0.473 & 0.706 & 0.8742 & 0.0556 \\
\hline Catalase & 0.631 & 0.575 & & 0.445 & & 0.9314 & 0.0592 \\
\hline Eigenvalue & 6.99 & 3.31 & 2.91 & 1.46 & 1.06 & & \\
\hline Proportion(\%) & 41.11 & 19.47 & 17.13 & 8.57 & 6.22 & & \\
\hline Cumulative proportion(\%) & 41.11 & 60.58 & 77.71 & 86.28 & 92.50 & & \\
\hline
\end{tabular}

\section{Comprehensive evaluation of soil quality}

Nine important indicators were selected that expressed soil quality by comprehensive evaluation. The soil quality of stand $\mathrm{H} 1$ is highest score (Table 6). At the same density, 
the 20-40 cm soil layer generally owns higher scores than the $0-20 \mathrm{~cm}$ soil layer, with the exception of stand H4. Stand $\mathrm{H} 4$ had the highest score in $0-20 \mathrm{~cm}$ soil layer, but lowest score in $20-40 \mathrm{~cm}$ soil layer.

Table 6. Comprehensive evaluation of soil depth under different densities

\begin{tabular}{c|c|c|c|c|c|c}
\hline Stand & Layer/cm & Physical properties & Chemical properties & Soil enzyme activities & Score & Mean \\
\hline \multirow{2}{*}{ H1 } & $0-20$ & 0.0326 & 0.1204 & 0.0650 & 0.2180 & \multirow{2}{*}{0.2279} \\
& $20-40$ & 0.0197 & 0.1443 & 0.0738 & 0.2378 & \\
\hline \multirow{2}{*}{ H2 } & $0-20$ & 0.0305 & 0.1161 & 0.0608 & 0.2074 & \multirow{2}{*}{0.2131} \\
& $20-40$ & 0.0439 & 0.1103 & 0.0647 & 0.2188 & 0.2020 \\
\hline \multirow{2}{*}{ H3 } & $0-20$ & 0.0231 & 0.1208 & 0.0582 & 0.2116 \\
& $20-40$ & 0.0357 & 0.1195 & 0.0659 & 0.2211 & \\
\hline \multirow{2}{*}{ H4 } & $0-20$ & 0.0401 & 0.1358 & 0.0647 & 0.2406 & \multirow{2}{*}{0.2064} \\
& $20-40$ & 0.0090 & 0.0977 & 0.0655 & 0.1721 & \\
\hline
\end{tabular}

\section{Discussion}

\section{The relationship between soil layer and soil quality}

The soil quality of different soil layers is different, mainly manifested in the differences in chemical properties and soil enzyme activities. In physical properties, the soil moisture and soil aeration in $0-20 \mathrm{~cm}$ soil layer are higher than those in $20-40 \mathrm{~cm}$ soil layer, which may be related to the soil composition. There are loose soil particles and large gaps between the gravels in $0-20 \mathrm{~cm}$ soil depth. Because of that, water is easily lost from topsoil to deep soil layer. Therefore, the soil moisture in $20-40 \mathrm{~cm}$ layer is higher.

The activity of catalase and acid phosphatase can better reflect soil nutrient condition (Qiu et al., 2010). The activity of catalase and acid phosphatase in 20-40 cm soil layer is lower than that in 0-20 cm soil layer, indicating that soil nutrition decreased with soil layer increase. Urease activity can be used to characterize soil nitrogen content (Qiu et al., 2010). The content of urease activity of stand $\mathrm{H} 1$ and $\mathrm{H} 2$ in the $0-20 \mathrm{~cm}$ soil layer is higher than that in 20-40 cm soil layer, while the content of urease of stand $\mathrm{H} 3$ and $\mathrm{H} 4$ has the opposite trend. The trend of total nitrogen is similar to urease. But the content of available nitrogen in $0-20 \mathrm{~cm}$ soil layer is better than that in $20-40 \mathrm{~cm}$ soil layer. The underground whiproot system of bamboo forests are sensitive to soil nutrient (Zhang et al., 2018). The content of soil nutrient in $0-20 \mathrm{~cm}$ is higher than that of $20-40 \mathrm{~cm}$ soil layer, which may be related to the distribution, secretion and residues of root can effectively accumulate nutrients, and loose soil conditions in $0-20 \mathrm{~cm}$ soil layer are also conducive to microbial decomposition of litter (Qi, 2009). The decomposition of litter produces a large amount of nutrients to return to the soil, so the nutrients in $0-20 \mathrm{~cm}$ soil layer are higher than $20-40 \mathrm{~cm}$. The $20-40 \mathrm{~cm}$ soil layer has relatively few root systems, and soil nutrients gradually decrease with increasing soil depth. The content of nutrient elements and their supply significantly affect root competition and distribution (Markham and Halwas, 2011; Murphy et al., 2013). Plants determine the distribution of root systems by integrating resources within their habitats (Cahill et al., 2010). It can be inferred that the root systems of Dendrocalamus minor var. amoenus are mainly distributed at $0-20 \mathrm{~cm}$. 


\section{The relationship between stand density and soil quality}

Plant nutrients mainly come from soil nutrients. There was a positive correlation between total nitrogen, urease, available potassium, available phosphorus with the stand density. Soil moisture and total nitrogen are the most important factors affecting plant functional characteristics (Ding et al., 2011). The higher the soil nitrogen content, the higher the root tissue density (Yang et al., 2014). The growth of five tree species is restricted by phosphorus in sandy coast (Qiu et al., 2017). Abundant soil nutrition promoted the increase ramets density of Dendrocalamus minor var. amoenus. The higher nitrogen content in the soil, the plant allocate nutrients into the above ground, increasing the number of ramets and biomass to adapt to the environment (Yue et al., 2002, 2004, 2005). This shows that the correlation between stand density and soil quality is greater. The adaptability of different species to soil nutrients is different. The soil nutrient of Phyllostachys edulis rises first and descends later with the stand density (Fan et al., 2015). The stand of Pinus tabulaeformis and Acacia sylvestris showed the opposite trend, and the nutrient content decreased with the increase of the stand density (Vesterdal et al., 1995; Xu et al., 2008). There may be different strategies for resource adaptation and biomass allocation of different species (Hoffman, 2010). The ramet density of Chimonobambusa tumidinoda and Pleioblastus maculata decreased with increasing availability of water resources (Dong et al., 2002; Liu et al., 2004). In this study, there was no significant difference in soil moisture content and volume weight between different densities. It may be that the species of Dendrocalamus minor var. amoenus is more resistant to drought or has adapted to drought environment.

The activity of catalase can reflect soil nutrient condition (Qiu et al., 2010). The activity of catalase decreases with increasing stand density, indicating that stand density increases with soil nutrient decrease. In the $20-40 \mathrm{~cm}$ soil layer, the total phosphorus, total potassium, and available nitrogen content had a negative correlation with stand density. On a small scale, the pachymorph of clonal plants increases the contact chance of ramets and easily occupy local resource (Turkington and Harper, 1979; Dong, 2011). Dendrocalamus minor var. amoenus is a phalanx clonal plant with close arrangement of its ramets, which is likely to form a pattern of local resource monopoly. High stand density increases soil nutrient consumption and inhibits the growth of underground roots. Beside that, high canopy density also reduces light in the forest and weakens soil microbial activity (Zhao, 2009; Ren, 2012). The root system consumes soil nutrients, and the movement of nutrient elements from the soil to the plant become faster, which causes the soil nutrients gradually decrease (Shanmughavel and Francis, 1997).

\section{Comprehensive evaluation of soil quality}

In this study, nine representative indicators were screened by principal component analysis, which are different to other research results. Previous studies show that eleven and nine indicators were selected to represent the soil quality of Phyllostachys edulis forest in subtropical climate (Fan et al., 2015; Chen, 2015). The difference may be related to soil types, site conditions, and indicators selected. In this study, we did not measure organic matter indicator, which has certain differences with other research results. Because the sandy coast is mainly inorganic minerals and the carbon content is very small (Huang and Chen, 1994; Griffith et al., 2009).

The comprehensive scores of soil quality at different stand densities are quite different. It means that soil properties of different stand densities are different (Table 6). 
In physical properties, the highest score in $0-20 \mathrm{~cm}$ soil layer is stand $\mathrm{H} 4$, but the highest score in $20-40 \mathrm{~cm}$ soil layer is stand $\mathrm{H} 2$. In the chemical properties, the highest score in $0-20 \mathrm{~cm}$ soil layer is stand $\mathrm{H} 4$, and the highest score in $20-40 \mathrm{~cm}$ soil layer is stand H1. In soil enzyme activities, the highest scores in 0-20 cm and $20-40 \mathrm{~cm}$ soil layer were stand $\mathrm{H} 1$. The comprehensive scores are ranked as: stand $\mathrm{H} 1>$ stand $\mathrm{H} 2>$ stand H3> stand H4. Thus, the higher the stand density, the lower the comprehensive score of soil quality. Dendrocalamus minor var. amoenus is a pachymorph species with many short individual spacers. These spacers are under great pressure to compete with light resources and soil nutrients. Therefore, low stand density get high comprehensive score.

\section{Conclusion}

The introduction of Dendrocalamus minor var. amoenus in sandy coast has gained good effect for stability of artificial forests and society economic. Soil properties of different densities is different. This study shows that the highest comprehensive score of soil quality with is stand $\mathrm{H} 1$. This stand density is good for soil quality. We recommend that diseased, old and dead ramets should be removed in future forest management. Meanwhile, topsoil should be protected, which is conducive to improving soil quality and forest productivity. Future researches should focus on the chemical elements balance in bamboo ramets, the root distribution and nutrient of different organs to reveal the fact that different stand densities could be formed with similar situation. Comparing different functional traits and their allometric growth relationships at different densities. The purpose of this study is to find a better stand density for soil quality. In coastal shelter forests, the wind resistance of bamboo clusters are also an extremely important concern, and it should be continuously paid attention in future research.

Acknowledgements. The authors are thankful to Dr Muhammad Waqqas. Khan Tarin for his help to manuscript revised. This project was jointly supported by science and technology major projects of Fujian province (2010N5002; 2013NZ0001). Foundation for Scientific and Technological Innovation of Fujian Agriculture and Forestry University (KF2015085; CXZX2017097).

\section{REFERENCES}

[1] Bao, B. D. (2005): Analysis of soil agricultural chemistry. - Beijing: Higer Education Press.

[2] Cahill, J. F. Jr., McNickle, G. G., Haag, J. J., Lamb, E. G., Nyanumba, S. M., St Clair, C. C. (2010): Plants integrate information about nutrients and neighbors. - Science 328: $1657-1657$.

[3] Chen, Y. (2015): Indices and evaluation of Phyllostachys pubescens Forest soil fertility quality in central scenic area bamboo sea of southern Sichuan. - Sichuan Agricultural University Dissertation, 89p.

[4] Chen, Q. Q., Li, D. Z. (2015): Kin recognition in Setaria italica under the condition of root segregation. - Chinese Journal of Plant Ecology 39(12): 1188-1197.

[5] Ding, J., Wu, Q., Yan, H., Zhang, S. R. (2011): Effects of topographic variations and soil characteristics on plant functional traits in a subtropical evergreen broad-leaved forest. Biodiversity Science 19(02): 158-167.

[6] Dong, W. Y., Huang, B. L., Xie, Z. X., Xie, Z. H., Liu, H. Y. (2002): The Ecological Strategy of Clonal Growth of Qiongzhuea tumidinoda Under Different Levels of Water 
Resource Supply. - Journal Of Nanjing Forestry University (Natural Science Edition) 06: 21-24.

[7] Dong, M. (2011): The ecology of clonal plants. - Beijing: Science press.

[8] Fan, S. H., Zhao, J. C., Su, W. H., Yu, L., Yan, Y. (2015): Comprehensive Evaluation of Soil Quality in Phyllostachys edulis Stands of Different Stocking Stocking Densities. Scientia Silvae Sinicae 10: 1-9.

[9] Griffith, A. D., Kinner, D. A., Tanner, B. R. (2009): Nutrient and Physical Soil Characteristics of River Cane Stands, Western North Carolina. - Castanea 74(3): 224235.

[10] Hoffman, M. K. (2010): Patterns of recruitment and young culm morphology in Arundinaria gigantea ([Walt.] Muhl.) canebrakes in western North Carolina. - Western Carolina University Dissertations \& Theses.

[11] Huang, Q. W., Chen, Y. Q. (1994): Study of the properties of coastal sandy soil in Euphoria longana Plantation. - Acta Ecologica Sinica 02: 180-187.

[12] Japet, W., Zhou, D. W., Zhang, H. X. (2009): Evidence of phenotypic plasticity in the response of Fagopyrum esculentum to population density and sowing date. - Journal of Plant Biology 52(4): 303-311.

[13] Li, Q., Zhou, B. Z., An, Y. F., Xu, S. H. (2014): Root system distribution and biomechanical characteristics of Bambusa oldhami. - Chinese Journal of Applied Ecology 25(05): 1319-1326.

[14] Liu, Q., Li, Y. X., Zhong, Z. C. (2004): Effects of moisture availability on clonal growth in bamboo Pleioblastus maculata. - Plant Ecology 173(1): 107-113.

[15] Luo, R. X., Zhang, C. X., Wang, F. S., Liu, G. H. (2009): A Study on the Root distribution of Three Bamboo Species and Their Soil Anti-scouribility. - Journal Of Bamboo Research 28(04): 23-26.

[16] Maherali, H., Delucia, E. H. (2001): Influence of climate-driven shifts in biomass allocation on water transport and storage in ponderosa pine. - Oecologia 129(4): 481-489.

[17] Markham, J., Halwas, S. (2011): Effect of neighbour presence and soil volume on the growth of Andropogon gerardii Vitman. - Plant Ecology \& Diversity 4: 265-268.

[18] Murphy, G. P., File, A. L., Dudley, S. A. (2013): Differentiating the effects of pot size and nutrient availability on plant biomass and allocation. - Botany 91: 799-803.

[19] Qi, L. H., Zhang, X. D., Zhou, J. X., Peng, Z. H., Yue, X. H., Huang, L. L. (2009): Soil Microbe Quantities, Microbial Carbon and Nitrogen and Fractal Characteristics under Different Vegetation Restoration Patterns in Watershed, Northwest Hunan. - Scientia Silvae Sinicae 45(08): 14-20.

[20] Qiu, X. K., Dong, Y. J., Wan, Y. S., Hu, G. Q., Wang, Y. H. (2010): Effects of Different Fertilizing Treatments on Contents of Soil Nutrients and Soil Enzyme Activity. - Soils 42(02): 249-255.

[21] Qiu, L. J, Hu, H. T., Lin, Y., Ge, L. L., Wang, K. Y., He, Z. M., Dong, Q. (2017): Nutrient resorption efficiency and C:N:P stoichiometry of Eucalyptus urophylla $\times$ E. grandis of different ages in a sandy coastal plain area. - Chinese Journal of Applied \& Environmental Biology 23(04): 739-744.

[22] Ren, L. N., Wang, H. Y., Ding, G. D., Gao, G. L., Yang, X. J. (2012): Effects of Pinus tabulaeformis Carr.plantation density on soil organic carbon and nutrients characteristics in rocky mountain area of northern China. - Arid Land Geography 35(03): 456-464.

[23] Shanmughavel, P., Francis, K. (1997): Balance and turnover of nutrients in a bamboo plantation (Bambusa bambos) of different ages. - Biology and Fertility of Soils 25(1): 6974.

[24] Tu, Z., Chen, L., Yu, X., Zheng, Y. (2014): Rhizosphere soil enzymatic and microbial activities in bamboo forests in southeastern China. - Soil Science and Plant Nutrition 60: 134-144. 
[25] Turkington, R., Harper, J. L. (1979): The growth, distribution and neighbour relationships of Trifolium repens in a permanent pasture: VI. Conditioning effects of neighbours. - The Journal of ecology 77(3): 734-746.

[26] Vesterdal, L., Dalsgaard, M., Felby, C. (1995): Effects of thinning and soil properties on accumulation of carbon, nitrogen and phosphorus in the forest floor of Norway spruce stands. - Forest Ecology \& Management 77: 1-10.

[27] Wang, Q., Su, Z. X., Zhou, P., Xia, L. (2004): Density Regulation of Clonal Growth of Neosinocalamus affinis in Different Habitats. - Journal Of China West Normal University (Natural Sciences) 04: 380-387.

[28] Xu, S. K., Wang, X. E., Xie, T. F., Zeng, F., Huang, L. M. (2008): Soil Fertility of Young Acacia auriculiformis Stands with Different Densities. - Journal of South China Agricultural University 29(2): 79-81.

[29] Yang, S. S., Wen, Z. M., Miao, L. P., Qi, D. H., Hua, D. W. (2014): Responses of plant functional traits to micro-topographical changes in hilly and gully region of the Loess Plateau, China. - Chinese Journal of Applied Ecology 25(12): 3413-3419.

[30] Yang, Q. P., Ouyang, M., Yang, G. Y., Song, Q. N., Guo, C. L., Fang, X. M., Chen, X., Huang, L., Chen, F. S. (2016): Research on ecological stoichiometry in bamboos: From biological basis to applications in sil-viculture of bamboo forests. - Chinese Journal of Plant Ecology 40(03): 264-278.

[31] Yue, C. L., Wang, K. H., He, Q. J., Weng, F. J. (2002): Comparative research on clonal growth of Phyllostachys praecox in different conditions of soil nitrogen content. - Journal of Bamboo Research 21(1): 38-40, 45-45.

[32] Yue, C. L., Chang, J., Wang, K. H., Zhu, Y. M. (2004): Response of clonal growth in Phyllostachys praecox f. prevernalis to changing light intensity. - Australian Journal of Botany 52(2): 171-174.

[33] Yue, C. L., Wang, K. H., Zhu, Y. M. (2005): Morphological plasticity of clonal plant Phyllostachys praecox f. prevernalis (Poaceae) in response to nitrogen. - Annales Botanici Fennici 42(2): 123-127.

[34] Zhang, M. M., Guan, F. Y., Fan, S. H., Lu, Y. S., Zhan, M. C., Yan, Y. J. (2018): Research Progress on Influencing Factors of Soil Nutrient Variation in Bamboo Forest. World Forestry Research 31(04): 18-22.

[35] Zhao, R. E. (2009): Root Distribution Pattern in Mixed Forest Stands of Pinus massoniana anti Pleioblastus amarus. - China Forestry Science And Technology 23(02): 77-79.

[36] Zhao, R. D., Fan, J. B., He, Y. Q., Song, C. L., Tu, R. F., Tan, B. C. (2012): Effects of Stand Density on Soil Nutrients and Enzyme Activities in Pinus massoniana Plantation. Soils 44(02): 297-301. 